\title{
IdeAs
}

Idées d'Amériques

$17 \mid 2021$

Villes et culture dans les Amériques

\section{Latin American, North American and Inter- American Studies in Germany}

Peter Birle

\section{(2) OpenEdition}

1 Journals

Electronic version

URL: https://journals.openedition.org/ideas/10704

DOI: 10.4000/ideas.10704

ISSN: 1950-5701

Publisher

Institut des Amériques

Electronic reference

Peter Birle, "Latin American, North American and Inter-American Studies in Germany", IdeAs [Online] 17 | 2021, Online since 01 March 2021, connection on 03 June 2021. URL: http:// journals.openedition.org/ideas/10704 ; DOI: https://doi.org/10.4000/ideas.10704

This text was automatically generated on 3 June 2021

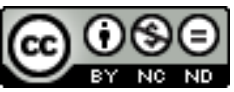

IdeAs - Idées d'Amériques est mis à disposition selon les termes de la licence Creative Commons Attribution - Pas d'Utilisation Commerciale - Pas de Modification 4.0 International. 


\title{
Latin American, North American and Inter-American Studies in Germany
}

\author{
Peter Birle
}

\section{Introduction}

1 This article deals with the development of research and teaching on the Americas in Germany since the beginning of the $20^{\text {th }}$ century. A remark on the terms used in Germany seems necessary: The German terms Amerikanistik and Amerikastudien (American Studies) are used to refer to the United States and Canada. The university discipline Amerikanistik sees itself as a philology dealing with the language and culture of the United States of America. American Studies, on the other hand, also deals with the history, politics, society and culture of the United States (and to a lesser extent Canada) from an interdisciplinary perspective. Approaches relating to the entire American continent are referred to as Inter-American Studies. They exist as a subject of study only at one German university (Bielefeld). However, since the beginning of the $21^{\text {st }}$ century, an examination of the Americas that goes beyond traditional geographical divisions in research and teaching has also taken place within the framework of Transregional Studies, Global History and Atlantic Studies, which, however, are not limited to a preoccupation with the Americas.

2 The article first describes the state of research on Latin American Studies, American Studies, and Inter-American Studies in Germany. On this basis, I will outline central lines of development in the three areas, referring also to important institutes, research institutions, journals and professional associations. 


\section{The state of research} in 1992: the Handbook of German-Language Latin American Studies ${ }^{1}$ contains contributions on 27 subject areas. In 1993, a compendium was published with information on institutions, scholars and experts dealing with Latin America in Germany, Austria and Switzerland. ${ }^{2}$ In 2012, the Ibero-American Institute in Berlin published a study that considered developments in 14 disciplines in the humanities and social sciences. ${ }^{3}$ Recent contributions discuss developments in the social sciences, Latin American studies during the Cold War, and the activities of the German Latin America Research Association (ADLAF), which has existed since the late 1960s. ${ }^{4}$

4 The development of American Studies has been the subject of a number of journal articles. They discuss for example the development of the field in the first half of the $20^{\text {th }}$ century, the reconstruction of American studies at German universities after 1945, trends at the beginning of the $21^{\text {st }}$ century, and the state of Canadian Studies. ${ }^{5}$

There have been only a few surveys of the field of Inter-American Studies. One exception is the essay by Piszarz-Ramírez. In addition, there are contributions that deal with Inter-American Studies in programmatic terms, focusing in particular on its basic framework and objectives as well as on the linkages between different spatial and disciplinary perspectives. ${ }^{6}$

The future of Area Studies as well as the topics of Regional Studies and Transregional Studies have received considerable attention from German researchers since the late 1990s. The Routledge Handbook on Transregional Studies, edited by cultural historian Matthias Middell, who teaches at the University of Leipzig, offers a current stocktaking from numerous perspectives. ${ }^{7}$

\section{Latin American Studies}

7 From the beginning of the $20^{\text {th }}$ century, foreign trade generated a need for information, giving impetus to scientific research on foreign countries. Above all, there was an interest in studying the possible markets for the sale of German industry. Among the first historical works devoted to Latin American countries were investigations of German colonies, colonial history, and German emigration. Comprehensive literary research on Latin America has only taken place since the 1960s, with the boom in Latin American literature playing a strong role. Since the 1960s, impulses for social science research on Latin America have come from the institutionalization of a national development policy and the activities of the political foundations. Nevertheless, unlike research on the United States (see above), there have never been any political guidelines or planning on the part of governments for research on Latin America. The political system of the Federal Republic of Germany ensured that decisions on the establishment of chairs and study programs were generally not made by national institutions, but at the decentralized level, even though today the Federal Ministry of Education and Research (BMBF) can provide important stimuli for research by setting up funding lines.

8

Research on Latin America in the fields of economics, social sciences and humanities takes place at more than 50 locations. About $80 \%$ of the scientific positions are in the 
university sector, $20 \%$ at non-university research institutions. Research on Latin America is only weakly institutionalized in most fields. Only about a quarter of the more than 150 university chairs have an explicit mention of Latin America in their job profiles. ${ }^{8}$ The main teaching and research centers include the Institute for Latin American Studies at Freie Universität Berlin, the Ibero-American Institute in Berlin, and the GIGA Institute for Latin American Studies in Hamburg. Two large collaborative projects funded by the BMBF, each involving several German universities and research institutions in addition to Latin American partners, are currently playing an important role in research on and networking with Latin America: the Maria Sibylla Merian Centre Conviviality-Inequality in Latin America, and the Maria Sibylla Merian International Centre for Advanced Studies in the Humanities and Social Sciences. The most important scientific journals published in Germany with reference to Latin America are Anuario de Historia de América Latina, Iberoamericana. América Latina - España - Portugal, Journal of Politics in Latin America, Indiana, and Revista Internacional de Lingüística Iberoamericana.

9 In addition to ADLAF, the German Hispanic Association, the German Lusitanian Association, and the German Romance Studies Association also represent the interests of scientists concerned with Latin America. In the professional associations of some other disciplines, there are regional groups that deal specifically with Latin America, for example in the fields of geography, Mesoamerican studies and sociology.

\section{Teaching and research on the U.S. and Canada}

10 The scholarly study of the United States in Germany received important impulses from the rise of the U.S. as a world power toward the end of the $19^{\text {th }}$ century. Nonetheless, after the end of World War I, the idea that there was too little knowledge of the United States in Germany became widespread. This led to an upswing in American Studies in the years of the Weimar Republic, the purpose of which was to gain a better understanding of U.S. culture, society and politics in order to better assess the U.S. as an international actor. The institutionalization of American Studies was limited to a few cities. In addition to Berlin, these included the universities in Göttingen, Hamburg, and Leipzig. After 1933, the extent of engagement with the United States at German universities remained constant. Only after the beginning of World War II, there was an ideologically, economically, and politically dominated expansion of university engagement with the United States. ${ }^{9}$

11 After World War II, political directives influenced the reestablishment and institutionalization of North American studies in West Germany. The American High Commission to Germany (HICOG) viewed the institutionalization of American Studies at German universities as an important component of its efforts to re-educate the German population after the experience of National Socialism. Like Political Science, American Studies was to play a function as a "democratization science". The reestablishment of American Studies took place with the involvement of a number of emigrants returning from the USA. Nevertheless, there was a relatively high degree of personal continuity among the teaching staff at German universities, especially in the study of American literature. As early as 1949, in Munich the America Institute arose, which became the largest institute of its kind in Germany. In the 1960s and 1970s, a growing institutionalization of American Studies at German universities took place. ${ }^{10}$ 
12 Today, it is possible to study subjects that deal explicitly with the U.S. (and to a much lesser extent (anada) at just about any German university. In addition to interdisciplinary programs in American Studies, many universities offer programs focused on literature and language, often in a combination of English / American Language Studies. The John F. Kennedy Institute for North American Studies at FU Berlin and the Department of English and American Studies at University of Frankfurt am Main developed into important centers of teaching and research. The most important professional association of North Americanists is the German Association for American Studies, founded in 1953. The association also publishes the journal Amerikastudien/American Studies and the monograph series American Studies.

For a long time, the study of Canada at German universities played only a marginal role. After the end of World War II, in West Germany, priority was given to the United States, in East Germany to the Soviet Union. Teaching and research activities on Canada started in the 1950s at the University of Marburg, later joined by Cologne and Kiel. Not least because of Canada's intensive cultural diplomacy, since the 1970s institutes for Canadian studies were established at more and more West German universities, for example in Augsburg, Bremen, and Trier. In 1979, a professional association was founded, the Association for Canadian Studies in German-Speaking Countries (GKS). Its interdisciplinary annual conferences are almost always held in the southern German town of Grainau, which over time has also become a center of international Canadian studies. Since 1981, the GKS publishes the interdisciplinary Journal of Canadian Studies and a book series of contributions to Canadian Studies. ${ }^{11}$

\section{Inter-American Studies}

The study of the inter-American system, inter-American relations, and the role of the United States in Latin America has always been an important part of Latin American studies. However, with the end of the Cold War, accelerated globalization, and the emergence of new discussions about the role of area studies, regional studies, global history, entangled histories, Atlantic relations, and other considerations in the humanities and social sciences that go beyond traditional geographical reference spaces, there have also been institutional realignments in the field of research and teaching. With the founding of the Center for InterAmerican Studies (CIAS) in 2011, Bielefeld University institutionalized an interdisciplinary examination of the entire American continent in research and teaching. In a programmatic essay, Olaf Kaltmeier described the central motives for the establishment of the new program. The starting point is the criticism of territorial concepts of space and of a consideration of the USA and Latin America as separate units of analysis, because this would ignore interAmerican entanglements. In contrast, new spatial categories are necessary. Only by analyzing the relationships between global processes and area-based knowledge would new perspectives on globalized societies, nations and cultures be possible. The concept of spaces of entanglement plays a central role in this context. It is meant to capture transfers between regions, regional intrinsic logics, but also processes of deterritorialization and transculturation. From this perspective, an area is not considered a given entity, but a field of interaction and exchange between different actors. It is not limited to a concrete physical space, but has a variable geometry. The concept of 
entanglements aims to capture the geopolitical strategies of institutional actors as well as economic interests, power asymmetries, and everyday experiences. ${ }^{12}$

At CIAS, researchers and scholars from the fields of history, sociology, political science, theology, Latin American studies, American studies, literary studies, linguistics, cultural studies and media studies from several faculties work together. The central research fields include topics such as interculturality, coloniality and mediality. Since 2013, the BMBF-funded project "The Americas as Space of Entanglements" has been part of the Bielefeld research activities. An interdisciplinary journal dedicated specifically to the field of inter-American studies has been in existence since 2008: the e-journal fiar: forum for interamerican research. The individual issues are dedicated to specific topics, such as Identity Politics in the Americas and Beyond, Theorizing Hemispheric American Studies, Geopolitical Imaginaries in the Americas, Religion in the Americas, or Migrations between Spaces in the Americas and Beyond. In recent years, several handbooks have been published in collaboration with scholars from Europe and the Americas, presenting contributions on History and Society, Political Economy, and Culture and Media of the Americas. ${ }^{13}$

\section{NOTES}

1. See Werz, Nikolaus (ed.) (1992): Handbuch der deutschsprachigen Lateinamerikakunde. Freiburg: ABI 1992.

2. See Institut für Iberoamerika-Kunde (ed.) (1993): Deutschsprachige Lateinamerikaforschung. Institutionen, Wissenschaftler und Experten in Deutschland, Österreich und der Schweiz. Hamburg: ADLAF.

3. See Göbel, Barbara/ Birle, Peter (2012): Investigación sobre América Latina en Alemania en el ámbito de las Ciencias Económicas, las Ciencias Sociales y las Humanidades. Situación y perspectivas, Berlin: IAI.

4. See Ruvituso, Clara (2019). Sozialwissenschaftliche Lateinamerikaforschung in Deutschland. In: Werz, Nikolaus/ Maihold, Günther/Sangmeister, Harmut (eds.): Lateinamerika. Handbuch für Wissenschaft und Forschung. Baden-Baden: Nomos 2019, 93-102; Puhle, Hans-Jürgen: Between Academia and Politics. Latin American Studies in Germany During the Cold War, in: Latin American Perspectives 221, 45 (2018) 4, 69-97. Puhle addresses not only developments in West Germany, but also Latin American studies in the GDR. On ADLAF, see Birle, Peter / Nolte, Detlef (2019) (eds.): 50 Jahre Arbeitsgemeinschaft Deutsche Lateinamerikaforschung. Frankfurt a. M. / Madrid: Vervuert / Iberoamericana.

5. See Gassert, Philipp (2003): "Between Political Reconnaisance [sic] Work and Democratizing Science: American Studies in Germany, 1917-53." Bulletin of the German Historical Institute Washington, D.C. 32, 33-50; Grabbe, Hans-Jürgen (2003): 50 Jahre Deutsche Gesellschaft für Amerikastudien. In: Amerikastudien / American Studies, 48. 2, 159-184; Grabbe, Hans-Jürgen (2014): Amerikastudien als "kooperatives Experiment": 60 Jahre Deutsche Gesellschaft für Amerikastudien. In: Amerikastudien / American Studies, 59.2, 221-239; Strunz, Gisela (1999): American Studies oder Amerikanistik? Die deutsche Amerikawissenschaft und die Hoffnung auf Erneuerung der Hochschulen und der politischen Kultur nach 1945. Opladen: Leske und Budrich.On the state of Canadian Studies, see Klooss, Wolfgang (2019): From Individual Scholarship to Academic 
Institution: Canadian Studies in the German-Speaking Countries and Cultural Diplomacy. In S. Brooks (ed.): Promoting Canadian Studies Abroad. Soft Power and Cultural Diplomacy. Basingstoke: Palgrave Macmillan, 199-223.

6. See Pisarz-Ramirez, Gabriele (2018): "Chicano Studies and Inter-American Studies in Germany". Routledge Handbook of Chicana/o Studies, ed. By Denise A. Segura, Francisco A. Lomelí and Elyette Benjamin-Labarthe, 431-442, London: Routledge; Kaltmeier, Olaf (2014): "InterAmerican Perspectives for the Rethinking of Area Studies." forum for inter-american research 7.3: 171-182; Sadowski-Smith, Claudia \& Claire F. Fox (2004): Theorizing the Hemisphere InterAmericas Work at the Intersection of American, Canadian, and Latin American Studies. In: Comparative American Studies 2.1, 5-38.

7. See Middell, Matthias (ed.) (2019): The Routledge Handbook of Transregional Studies. New York, NY: Routledge.

8. See Göbel/Birle 2012.

9. See Gassert, 2003.

10. See Grabbe, 2003 and 2014.

11. See Klooss, 2019.

12. See Kaltmeier, 2014.

13. See Kaltmeier, Olaf et al. (eds.) (2019): The Routledge Handbook to the History and Society of the Americas. New York, NY: Routledge; Kaltmeier, Olaf et al. (2020): The Routledge Handbook to the Political Economy and Governance of the Americas. New York, NY: Routledge; Raussert, Wilfried (ed.) (2017): The Routledge Companion to Inter-American Studies. New York, NY: Routledge; Raussert, Wilfried et al. (eds.) (2020): The Routledge Handbook to the Culture and Media of the Americas. New York, NY: Routledge.

\section{AUTHOR}

\section{PETER BIRLE}

Dr. Peter Birle is Political Scientist. He heads the research department of the IberoAmerikanisches Institut in Berlin, Germany, and teaches at Freie Universität Berlin. His main research interests are Latin American Foreign Policies in Comparative Perspective, Regional Cooperation and Integration in Latin America, Comparative Analysis of Latin American Political Systems, and Knowledge Production in and about Latin America. Recent books: Las izquierdas latinoamericanas y europeas. Idearios, praxis y sus circulaciones transregionales en la larga década del sesenta. Madrid/Frankfurt a.M.: Iberoamericana/Vervuert 2021 (editor, with Enrique Fernández and Clara Ruvituso); Políticas públicas para la internacionalización de la educación superior en América Latina. Madrid/Frankfurt a.M.: Iberoamericana/Vervuert 2020 (editor, with Gabriela Michelini and Fernando Luján Acosta). For more information, see: https://www.iai.spk-berlin.de/en/ research/researchers/dr-peter-birle.html 